\title{
UTILIZING THE ENTREPRENEURIAL POTENTIALS OF MUSIC FOR SELF-RELIANCE IN A RECESSED NIGERIAN ECONOMY
}

\author{
Oghenemudiakevwe Igbi, Ph.D \\ Department of Music, College of Education, Agbor, Delta State, Nigeria.
}

\begin{abstract}
Since the attainment of independence in 1960, Nigeria has been plagued with a myriad of problems that have contributed in no small measure to impeding growth and development. This has further led to undiversified economy, recession, and unemployment. The failure of political office holders to deliver their electoral promises, coupled with their knack for corruption and self-aggrandizement have ensured that the growing population of Nigerians remains unemployed. The country's pathetic condition is further worsened by the annual influx of graduates into the labour market. In a bid to address the lingering challenges, governments in the last decade invested huge financial resources in areas like agriculture. But these efforts notwithstanding, the progress recorded in the sectors is still not commensurate with the huge finances channeled to them. However, the potentials of music in ameliorating the situation have not been explored enough, neither have graduates of music taken advantage of the entrepreneurial possibilities in music to become self-reliant. Utilizing data obtained through personal experiences and interviews, the paper periscopes the economic potentials of music for self-reliance, and challenges academic musicians to key in, take due advantage of them, by becoming more business minded. It is recommended that urgent steps be taken by government to earmark the needed funds for music and other performing arts, as a means of job creation. Becoming more business minded will enable music graduates be self-reliant and become employers of labour, thereby contributing their quota towards ameliorating the economic challenges being faced by the country.
\end{abstract}

Keywords: Music, Economic recession, Unemployment, Nigeria

\section{INTRODUCTION}

Often times in Nigeria, the news of an individual taking to the study of music in a tertiary institution is received with shock, disdain and ridicule. To many people, music is a discipline destined for dullards, and a last resort to acquiring formal education. As noted by Idamoyibo (2002:13), 'when one says he is studying music in a higher institution, the African society sees it as feminine, laziness, unseriousness, shortsightedness, nit-wittedness and so forth'. There are a 
International Journal of Arts and Humanities

ISSN: 2581-3102

Volume: 04, Issue: 03 "March 2020"

number of reasons for this erroneous impression. Music is one of the few professions that people who did not receive formal training in it practice. It is largely believed that studying music is unnecessary. Those who share this opinion, often mention the names of some popular musicians who became famous despite not studying music. There is also the concern of where graduates of music can secure jobs after graduation from the university. For instance, during this writer's undergraduate days, he remembers being quizzed by friends and neighbours; where are you going to work after school? As an art student, why did you not study Law? You could have studied Economics or Business Administration rather than Music! The sciences and social sciences have always had the nod over the arts in several facets. Thus, over the years, the arts have been plagued with biased policies by government, thereby creating the illusion of it being inferior, in comparison to the sciences and social sciences. Although there have been some improvement in the public perception of music as an academic discipline in the last two decades, many music graduates on their part have not done enough to improve the image of the discipline in the society. Apart from shying to disclose to people that they studied music, those who have shown the desire to practice music after their formal education have through their approach and inability to 'think out of the box', limited their job possibilities. For example, the most patronized jobs by music graduates are teaching and Church music practice as choirmasters and organists. Although teaching and Church music practice are noble options as regards job, there exist many other areas in music that graduates can exploit.

It is a known fact that the most affluent people in Africa are business men and women, and not necessarily salary earners. The music profession is two faceted. Firstly, like any other profession in the arts, sciences and social sciences, music affords one opportunities to work in organized sectors where salaries are earned; secondly, music is a viable business. However, the potentials in the area of music business have often been ignored by music graduates. The paper sets to challenge music graduates to take advantage of music business, with the aim of becoming selfreliant. Twenty music businesses are listed in the paper, that music graduates can establish, thereby becoming employers of labour. This is necessary because, the present economic situation of Nigeria demands that job seekers brainstorm on areas that are capable of enabling them thrive favourably. By so doing, the recession which has crippled many sectors of the country's development and the wellbeing of the populace in diverse ways will have little or no effect on graduates of music. Some scholars have already written on available job opportunities for music graduates (see Idamoyibo, 2002 and Olaniyan, 2002). However, the aim of this paper is not to recycle what has already been done by the above mentioned scholars by outlining jobs that await graduates of music. Rather, it is an addition to the pool of works on the viability of music in the labour market, by discussing the need to 'commodify' music through suggesting business areas in the music profession that academic musicians can thrive. The paper also aims to illuminate the minds of young music graduates on how they can become music entrepreneurs after school, 
International Journal of Arts and Humanities

ISSN: 2581-3102

Volume: 04, Issue: 03 "March 2020"

rather than teach or patronize Church music practice which is fast becoming over flooded. Even if they do, they can still be entrepreneurs in music.

\section{SOCIETAL VIEWS ON MUSIC AS A CAREER, AND OPINIONS ON REMUNERATION FOR MUSIC PRACTITIONERS}

Most times, people engage in music primarily as a hobby. Many music enthusiasts actively or passively participate in musical activities as a pastime or for relaxation. Hence, it is not uncommon hearing divided opinions about electing to take up music as a career. Of course, taking music as a profession implies receiving remuneration for services rendered. But while it is true that people reserve the right to choose any career of their choice that they believe will better their economic conditions, it suffices to note that music is the least considered amongst the numerous professions that are perceived to be lucrative - an opinion shared by the elite and nonelites. In religious circles for example, there have always been debates on whether Church musicians should be paid or not. This is majorly because of the age-long impression that Church musicians should not be entitled to wages since musical abilities are heavenly gifts. This inclination is not new, because the opinion has been shared in some traditional African societies for ages, where the reward for musicians is expected to come from divine forces, since it is believed that musical gifts are from them. It is therefore unacceptable to practice music for profit. The only return expected to be enjoyed by the musician is the esteemed veneration from society as an accomplished or proficient musician. Commenting on this practice among the Igbo of Nigeria, Ogisi (2006:102) observes that:

Music is a profession in which the skillful is recognized and socially respected, although it is not expected to be depended upon as a means of livelihood. This is so because, the Igbo regard musical competence or ability as a divine endowment that is trivialized when it is made a means of livelihood. Rather, a musician is expected to use it for the benefit of society while engaging in acceptable professions like farming, commerce, etc. Thus, for the Igbo, the adoption of music as a profession is a choice for the indolent and prostituting a divine endowment.

However, there is hardly any phenomenon that is not attributed to divine forces, including life, death, riches, bounteous harvest, and various gifts. But when such deliberations on remuneration surface, the debaters tend to forget that gifts come in different forms, and not just in music. Hunters who shoot without missing, farmers who have the fortune of tilling fertile lands yearly, traditional medical practitioners whose medicines are potent, etc, all believe they possess gifts that were divinely bequeathed to them. In other words, there is barely any skill that is not from the divine. 
International Journal of Arts and Humanities

ISSN: 2581-3102

Volume: 04, Issue: 03 "March 2020"

There are also a tangible number of people who practice music actively and earn a living from it. In whatever way one practices music, the underlying truth is that he/she must have undergone one form of training or the other. In traditional African societies, musicians undergo different stages of apprenticeship before they are regarded as professionals. Omibiyi-Obidike (1987) cited in Idolor (2001), rightly notes that although there are different stages of traditional music education, it is the second stage of training that is meant for those who aim to make music a profession. The training of such artistes according to Idolor (2001) 'involves equipping them with relevant skills to enable them play the music effectively, imbibe ensemble habits and raise the standard and quality of performance'. Even in tertiary institutions where music is studied, students are expected to offer courses in history, harmony/counterpoint, African music, ensemble studies, applied music, general musicianship, etc. Subsequently, it is required that they specialize in areas like composition, performance, African musicology, music media, music production, music education, conducting/directing, etc. The knowledge garnered from all these are not only expected to shape them into better individuals, but to prepare them with relevant skills that will enable them cope with the high demands of society in the area of music practice.

\section{MUSIC BUSINESS AND THE SOCIETAL PERCEPTION OF MUSIC AS A PRODUCT IN NIGERIA}

Anyone who primarily sets up a business, mobilizes labour, engages in production of goods, and offers professional services with the aim of generating profit is an entrepreneur. $\mathrm{He}$ is an innovator who harnesses his skills to meet the demands of his customers. In other words, failure to effectively harness skills, or even a lack of such often results in failed businesses and lost capital. Music, aside being an academic field, is a viable business. There are different business opportunities in music that are yet to be patronized especially by formally trained musicians. In the field of music, entrepreneurship is beyond gaining only the rudimentary knowledge of business. It also entails being technically sound and versatile in different areas of music. The businessman in the field of music is a consultant, to whom issues bothering on his trade are brought for expert solutions. His training will enable him advice customers appropriately on decisions to take.

The music industry is a complex conglomerate of networks, hence, music businesses come in different forms. There are businesses that involve buying and selling, others comprise rendering creative services, while others encompass offering of technical services. Music is a commodity that can be marketed for financial profit. It is therefore, certain that any finished music product must have undergone several stages of creation before it reaches its consumers. Subsequently, each stage of music production involves the services of experts. From the assembly of musical equipment/instruments, rehearsals, performance, recording, mixing, mastering, marketing of products, artiste management, etc, all require people that are knowledgeable in music to handle. 
International Journal of Arts and Humanities

ISSN: 2581-3102

Volume: 04, Issue: 03 "March 2020"

Even when such music is to be played at events for public consumption, disc jockeys and music media experts are needed to provide the right mix and determine when the music should be aired on radio or television. All these stages are categories of music business since they can generate tangible income, and it involves various sums of money to achieve. This notwithstanding, society tends not to recollect the fact that huge finances were involved in the production of music. For example, most families in Nigeria own televisions, cables/satellites, and CD/DVD players. Even the most impoverished families at least are often able to afford radios or smartphones that can play recorded music. But once music is being played on these devices, listeners hardly remember the fact that music is expensive, and that the music they are listening to is a commodity that cost the producers and artistes money. Apart from recorded music, there is no doubt that albeit slow, concert music has grown in terms of patronage in Nigeria. In Warri for example, people attend music concerts where various compositions by Western and African composers are performed. Staging such concerts are usually very capital intensive. Despite the fact that huge sums of money are required to rent the concert halls, sound equipment, print invitation cards/concert programmes, pay guest artistes, decorate the halls, sew costumes, and purchase musical scores, a tangible number of the audience is still often reluctant to contribute tokens to subsidize cost when appeals for donations are made. Even in cases where tickets are sold, the attendance is usually scanty. The situation where huge sums of money are realized from concerts in Warri seems to be only when political office holders grace the occasion. In this case, the owner of the ensemble or music director must have the right connections to attract such politicians or other affluent people, wherein they are designated 'special guest of honour', 'guest of honour', 'chairman of the occasion', etc. Even at that, most times, such affluent people may not necessarily be invited because they love art music; the motive for the invitation is usually clear donation. Even ensembles who sell tickets pay the price in another form - unimpressive turnout of audience. The few who are able to attract a sizeable audience do not get positive responses from the audience when appeals for donations are made since they had already purchased tickets. The reason for this scenario among the consumers is not farfetched; they see no need paying to listen to art music. This may not be unconnected to the African traditional setting, where audiences are not charged money to listen to or participate in musical activities. Donations are usually at the discretion of the listener who may decide to reward dexterous drummers, skilled dancers or singers with financial gifts. Rewards may also come from audiences in the form of eulogies during discussions or appraisal of a performance. It is also partly because many people who listen to live or recorded music are only concerned with the immediate appeal and satisfaction resulting from the sound they hear. How such artistic creation was made possible is not their problem. In this vein, Ogisi (2006:101) provides this apt observation:

[The Nigerian society] separates the importance of a product from the producer, the object from its maker, thus, raising the conclusion that the importance of a 
International Journal of Arts and Humanities

ISSN: 2581-3102

Volume: 04, Issue: 03 "March 2020"

product does not always confer improved status on the maker. In the daily workings of society, producers of goods and services are only remembered by a few consumers because in purchasing the product or paying for the service, the primary concern is the benefit that he/she derives from it. From this perspective, there exists a disconnect between the producer, the product and the user. This is the case with the musician and music in Africa. Society separates the musicians from his music. The regular attendance of gigs can be mistakenly interpreted as a love for the art of music or musician, whereas, it may be to satisfy other needs such as camaderie, company and catharsis. This observation could be interpreted as a love-hate relationship between the musician and his audience as displayed in their need of the product but not the producer. It is therefore evident that the importance of a product does not ordinarily confer status on the producer and the need for music is not synonymous with the love for music.

The views expressed above by Ogisi are very true of what obtains in Nigeria. As unfortunate as it may seem, music professionals have not done enough in commercializing music and bestowing a more commoditized status on it. Despite the fact that popular musicians have achieved some degree of success in this regard, society needs to come to terms with the reality that musical services rendered in whatever form should attract rewards (financial or material). Even if the aim of consuming such music is to soothe other non-musical desires or meet needs that are not in tandem with the love for the art, the consumers need be aware that music may even be a more essential commodity than other materials/products that are purchased with mouthwatering sums of money. In doing this, the onus rests more on the music practitioners themselves; that is, by taking pride in their art. They should also patronize more, those business areas in music that are capable of generating wealth. Unfortunately, such areas over the years, have been left for people with no formal education in music to handle, thereby, paving the way for the proliferation of substandard music in both content and delivery.

\section{THE EFFECTS OF ECONOMIC RECESSION AND UNEMPLOYMENT}

Any nation that is hit with recession is bound to be in an economic crisis. This includes inflation, high cost of goods and services, unemployment, and inability to provide basic infrastructure or maintain existing ones. This has been the tale of Nigeria in the last few years. Although the present administration of President Muhammadu Buhari alleged that mismanagement of funds by previous governments are majorly responsible for the present precarious situation, the truth remains that efforts directed at ameliorating the adverse effects of recession on the masses in the last couple of years have been futile. Among the plight being suffered by Nigerians include increase in foreign exchange and petroleum products, hike in the prices of food items, high cost of transportation and healthcare, while several moribund infrastructure have been left in their 
International Journal of Arts and Humanities

ISSN: 2581-3102

Volume: 04, Issue: 03 "March 2020"

dilapidated state. Even the billions of Naira channeled by government to the agricultural sector is yet to make any significant impact in the life of the common man. This notwithstanding, Nigerians made frantic efforts to engage in activities that will ensure their survival. One of the measures taken by Nigerians is the diversification of their sources of income. This became imperative, since salaries earned could no longer guarantee survival for many people, especially the cicil servants. It is therefore imperative, as a result of developments in the country, for music graduates to also diversify their areas of practice, by patronizing music businesses.

\section{THE NEED FOR DIVERSIFICATION WITHIN THE MUSIC PROFESSION}

The issue of diversification is mostly heard in Nigeria when references to the over dependence on crude oil as a means of revenue are made. In the last few years, it has been used together with entrepreneurship as an alternative to self-reliance, as a result of the unavailability of white-collar jobs in government establishments and oil multinationals. Teaching and Church music practice have become synonymous with oil company jobs in the field of music in Nigeria. That is to say, they are the most patronized jobs by graduates of music. In most cases, music students upon their admission, aspire to become secondary/primary school teachers and Church organists or choirmasters. This is partly because of the widespread opinion that the only vacancies open to music graduates is teaching, and working as Church musicians. Thus, most students after gaining admission into departments of music, as a result of the above opinion, live under the fallacy that teaching and Church music practice are the only jobs available to them after graduation. Obviously, these assumptions are corroborated by the fact that teaching and Church music jobs as organist and choirmaster, are indeed the most sought after jobs by music graduates. This trend has paved way for many to believe that the aforementioned are actually the most lucrative opportunities that exist in the labour market for graduates of music. Thus, many people graduate with the aim of becoming lecturers and Church musicians. Although, lecturing and Church music practice are indeed the readily available ventures given the economic situation of Nigeria, there is the possibility of combining private music business with lecturing. Another reason for the huge reliance on the Church for jobs is because, she (the Church) remains one of the chief patrons of art and gospel music; these areas account for a significant number of music graduates in terms of patronage. It may also be because of the Christian background of most music graduates, as most of them had their formative years in the Church. But these are not enough reasons why one would not spread his/her horizons to other areas. Why stick to teaching or Church music practice when there exist other opportunities in the business world of music? Idamoyibo (2002:18) observes that 'in some places, one is able to combine two or more of these jobs'. After citing some examples in Port Harcourt and Lagos, Idamoyibo goes further to ask: 'can any discipline be more lucrative than this?' Indeed, it is difficult to name five disciplines that are more lucrative than music. But the puzzle is if graduates of music have done enough to 
International Journal of Arts and Humanities

ISSN: 2581-3102

Volume: 04, Issue: 03 "March 2020"

take advantage of the rare characteristic of music as a sinecure, wherein after acquiring musical skills, one need not get soaked in sweat to earn a living. The business opportunities have not been patronized enough by music graduates. There is a perceived lopsidedness towards the Church music ministry, which is fast becoming over flooded with stiff competitions emerging on an annual basis. The annual influx of music graduates into the labour market, and the growing number of music enthusiasts learning piano/organ playing is although commendable, but also of grave concern to job seekers. The reason is that, there is now more competition in the Church for positions like choirmaster or organist. Another cause for worry is that when the music graduates have been employed in the Churches as organists or choirmasters, they seem to remain contented with those jobs. Whereas, working in the Church as a musician allows the freedom to engage in any other private practice. The services of the choirmaster or organist is mostly needed during choir rehearsals, Sunday services, and other events like weddings which under normal circumstances do not occur regularly. There is therefore, the possibility to also be an entrepreneur alongside working in a Church. The above also goes for teaching, where most music teachers work on part-time. The truth remains that, not everybody can become a lecturer or organist. If expertly handled, the business potentials that will be listed in the next section, are capable of allaying the fears of over flooding of manpower and competition in the Church and teaching sectors, since music entrepreneurs will have the privilege of becoming employers of labour rather than job seekers.

\section{HARNESSING VARIOUS BUSINESS POTENTIALS IN THE MUSIC PROFESSION FOR SELF-RELIANCE}

The utmost ambition of anybody who has acquired formal or informal training in any field of human endeavour is to be satisfied, and also generate income that will at least suffice to meet daily needs and be independent of others. This naturally leads to the quest for gainful employment or establishment of private businesses. The latter, which this study has been discussing, requires the acquirement of entrepreneurial skills, that will help such individuals thrive better. As mentioned earlier in the paper, there are a number of scholarly works already published on the available jobs for music graduates. These include working in art councils, Federal/State Ministries of Education, the Armed Forces/Police, Examination bodies like WAEC/NECO, in Tertiary/other institutions for higher education as lecturers, etc ${ }^{1 .}$ But working in all these organisations and parastatals require recruitment by government. We therefore hope to shift our focus to areas that can be individually established - music businesses. Some of the opportunities listed below can generate upwards of five hundred thousand Naira (N500, 000) monthly. Others like supply of musical instruments like organs can even generate profit of two million Naira (N2, 000, 000) and above, depending on the make and kind of organ supplied. 
International Journal of Arts and Humanities

ISSN: 2581-3102

Volume: 04, Issue: 03 "March 2020"

Institutions of higher learning in Nigeria should review their programmes in Music to accommodate courses that will prepare the music graduate become an employer of labour rather than a job seeker. An institution that has done this in Nigeria is Delta State University, (DELSU) Abraka. As I had noted elsewhere, 'it was deemed necessary [by the departmental board of studies and DELSU Senate] to broaden the scope of the syllabus to include other courses with appropriate credit units, that will enable graduates become more useful to society and be selfreliant. The thinking [of the department] was to open up other avenues for the music graduate outside being a Church musician, teacher or music scholar' (Igbi, 2017:227-228).

At a time when the few Universities in Nigeria running postgraduate programmes in Music mainly offered ethnomusicology, composition and music education as stress areas, DELSU Abraka included other areas of specialization like music technology, popular musicology, conducting and directing, music production and management, and performance (including dance, voice, piano, and various orchestral instruments) in her programmes. All these areas have been running from the undergraduate to doctoral levels since 2006, with a number of persons who successfully completed their programmes. Music students at DELSU (both undergraduate and postgraduate) also compulsorily undergo internship under the Students' Industrial Work Experience Scheme (SIWES) for a period of time. During the period of internship, they are sent to understudy a professional outside the university. The aim of this is to afford the students the opportunity of getting practical firsthand experience on his area of specialization outside the university.

Music business has mostly been left for music illiterates; the time is ripe for music graduates to wake up and be more proactive in their profession. Many music graduates have been lost to other fields of human endeavor partly because they are unaware of the viability of music business. Music graduates in Nigeria can consider setting up businesses in any or a combination of the under listed areas.

- $\quad$ Setting up a Conservatory

- Music Technology and Engineering

- Importation/Supply and Hiring of Musical Instruments and Sound Equipment

- Music Consultancy

- Presentation of Music Programmes on Television and Radio

- As Professional Soloist/Waxing of Pop and art music Albums

- Organization of Workshops/Seminars for choirs and other music practitioners

- Owning of Production Studios

- Establishment of Singing/Instrumental Ensembles and Dance Troupes

- Organizing Music Competitions 
International Journal of Arts and Humanities

ISSN: 2581-3102

Volume: 04, Issue: 03 "March 2020"

- Music Artiste Management

- Song Writing/Commissioned Compositions

- Talent Scout for Record Labels

- Music Marketing

- Creation of Mobile Applications and software for Music

- Music Blogging

- Music Publishing Companies

- Music Agent

- Theatrical/Film Music Director

- Sound Technician

\section{CONCLUSION AND RECOMMENDATIONS}

Consequent upon the findings arising from the study, it can be deduced that music is too broad a discipline, for practitioners to remain sandwiched between teaching and Church music practice. As was made manifest in the paper, there are several other prospects in the music profession that are yet to be patronized by trained musicians in Nigeria. It is hoped that the paper, having drawn the attention of stakeholders to these areas, will yield positive dividends, by not only invigorating more patronage of those areas, but enabling music to be seen beyond only a Church or academic affair. The time is ripe for academic musicians to diversify their interests with regards to professional practice, and embrace music business. Institutions that run music programmes are also encouraged to review their curricular to accommodate courses that will prepare the music graduate to function effectively in the business world. While the positives that derive from electing to take music education or Church music as careers are obvious, there is no doubt that it is expedient to embrace entrepreneurship in music, especially in a country like Nigeria, where white-collar jobs have become only a fantasy for job seekers. Although the hopes of the masses are repeatedly kept alive by greedy political office holders during speeches, symposia and campaigns, the reality on ground tends to affirm the presupposition that change remains unlikely. While this opinion is subject to debate, the truism that the involvement of academic musicians in business will diversify the economy and open up several avenues for practitioners to practice their art cannot be contested. It is therefore recommended that the entrepreneurial potentials discussed in the paper be embraced by all and sundry in the music profession. As was noted in the paper, academic musicians have over the years seemed to limit their potentials by clustering themselves in the two areas of teaching and Church music; a trend that may have contributed to the erroneous societal perception of music as a profession that has limited options in the labour market. From the issues raised in the paper, it is clear that it is requisite to embrace music business as a way of guaranteeing self-reliance in a recessed economy like Nigeria. While music 
International Journal of Arts and Humanities

ISSN: 2581-3102

Volume: 04, Issue: 03 "March 2020"

graduates strive to diversify their interests, the government at the state and federal levels must change their attitude towards funding music and other performing arts. Adequate funds should be budgeted by government for various music businesses and other music activities through the Ministries of Arts and Culture. There is no doubt that this will boost the Gross Domestic Product (GDP) of the country, thereby facilitating stability in the Nigerian economy and eradicating the scourge of recession that Nigerians have had no choice but to adapt to since 2016.

\section{REFERENCES}

Idamoyibo, O. (2002). 'Impressionistic Views on the Study of Music in Nigeria'. In Idolor, E. G. (Ed.). Music in Africa: Facts and Illusions. Ibadan: Stirling-Horden Publishers. Pp: 1223.

Idolor, G. E. (2001). 'Traditional Music Training in Okpe Disco'. An Excerpt from: Okpe Disco: A Neo-traditional Nigerian Popular Music Genre. An Unpublished $\mathrm{PhD}$ Thesis, University of Ibadan.

Igbi, O. (2017). A Retrospective Evaluation of Tertiary Music Education in Delta State and its Impacts on Society'. ICHEKE: A Multidisciplinary Journal of the Faculty of Humanities, Ignatius Ajuru University of Education, Port Harcourt. Vol. 15. No. 2. Pp: 223-238.

Ogisi, A. A. (2006). 'A Theoretical Interpretation of the Status of the Musician in Contemporary Nigeria'. Awka Journal of Research in Music and the Arts. Vol. 3. Pp. 100-113.

Ogisi, A. A. (2008). 'The Development of Nigerian Art Music, 1920-2000'. Journal of the Association of Nigerian Musicologists, Special Edition. Pp: 151-163.

Olaniyan, O. (2002). 'Music as a Career: Challenges and Prospects in a Changing African Society'. In Idolor, E. G. (Ed.). Music in Africa: Facts and Illusions. Ibadan: StirlingHorden Publishers. Pp: 38-45. 